\title{
DATE PALM DISEASES AND PESTS (CASE OF BAYOUD DISEASE: VASCULAR FUSARIUM) FUSARIUM OXYSPORUM F. SP. ALBEDINIS IN THE WILAYA OF ADRAR
}

\author{
Hadjraoui $K^{*} \cdot 1$, HAIDA W*1. , Kerboub $Y^{2}$ \\ 1: Laboratory of Physiopathology and Biochemistry of Nutrition (PpBioNut), University of Tlemcen. \\ 2: University of Ibn Khaldun, Faculty of nature and life sciences, Tiaret Algeria.
}

Corresponding Author: Hadjraoui K, university of Tlemcen, Algeria; Email: Meninaeco@ yahoo.com

$"$ : the contribution of these two authors is identical

Article history: Received: 20 March 2017, Revised: 10 April 2017, Accepted: 20 July 2018

\section{Abstract}

The date palm occupies an important place in agriculture in the Saharan areas and contributes to the preservation of the fragile oasis ecosystem, threatened by desertification. Fusarium wilt of the date palm (phoenix dactylefra L.) known locally as "Bayoud" whose scientific name is Fusarium oxysporum f. sp. albedinis, poses a serious threat to the economy and society. As part of this work, we will try to better know the pathogen to better combat.

The isolation of the fungus led us to obtain 05 isolates; their macroscopic characterization revealed two different morphotypes: the cottony morphotype and the ras mucous morphotype and their microscopic characterization the presence of hyaline and septate mycelium, with short monophialids on which microconidia are found, as well as the presence of macroconidia and chlamydospores.

Key words: Phoenix dactylifera, vascular fusariosis (Bayoud), Adrar.

\section{Introduction}

The date palm, a species well adapted to the arid and desert climate, occupies an important place in the agricultural production systems of the Saharan zones. The date palm contributes a large share of farmers' farm income, thus enabling the stability of populations in this difficult environment. Date palm cultivation is subject to various phytosanitary problems that hinder its development and extension. Bayoud, vascular fusariosis of the date palm (phoenix dactylifera $\mathrm{L}$ ) caused by a fungus of telluric origin Fusarium oxysporum f. sp. Albedinis (Killian and Mayor), is the most destructive and most threatening disease in North Africa. It is widespread mainly in Morocco and in a large part of the palm groves of Algeria (Pereau Leroy 1958, Djerbi 1982, Brac and Benkhalifa 1991). Indeed, over a century, it has destroyed more than ten million palm trees in Morocco (Pereau - Leroy 1958, Sedra 2005a) and three million in Algeria (Djerbi 1982, Sedra 2005a). In recent years, the disease has also been found in Adrar and Tagant palm groves in Mauritania (Sedra 1995, 1999, 2003a). The disaster caused by the Bayoud does not stop at the genetic erosion caused by the disappearance of many varieties among the best, but also leads to the accentuation of the desertification and the impoverishment of the phoeniculturists who end up emigrating. The elimination of diseases by the various control treatments can not succeed without passing through the fullest possible knowledge of the pathogenic agents of the culture.

In this perspective our work has the following objectives: i) Prospecting and sampling from the palm trees; ii)- Isolation of Fusarium oxysporum f. sp. albedinis agent of vascular fusariosis of the date palm; iii). Morphological characterization of the different isolates obtained. 


\section{Material and methods:}

\section{Study Area Presentation}

Adrar, the first of the 48 Algerian wilayas, according to the administrative division of 1995, is a Saharan city located in the southwest of Algeria. It is located between $1^{\circ}$ and $3^{\circ}$ West of the Greenwich line and between the circle $20^{\circ}$ to $30^{\circ}$ North of the equator, bordered on the north by the wilayas of El Bayadh and Ghardaia, to the west by the wilayas of Bechar and Tindouf, to the east by the wilaya of Tamanrasset, and to the south by Mauritania and Mali (figure 1). The Wilaya of Adrar has for main economy the agriculture with in particular its irrigation system the "foggara". The climate of the wilaya of Adrar is of desert type continental and the rainfall is extremely weak and even insignificant in the city of Adrar. The annual average over the period 1975-1984 is $12 \mathrm{~mm}$ (KEBIR, 2011). Four regions constitute the wilaya of Adrar:

- The Gourara (Timimoune region).

- The Touat (region of Adrar).

- The Tidikelt (region of Aoulef).

- The Tanezrouft (Bordj Badji Mokhtar region).

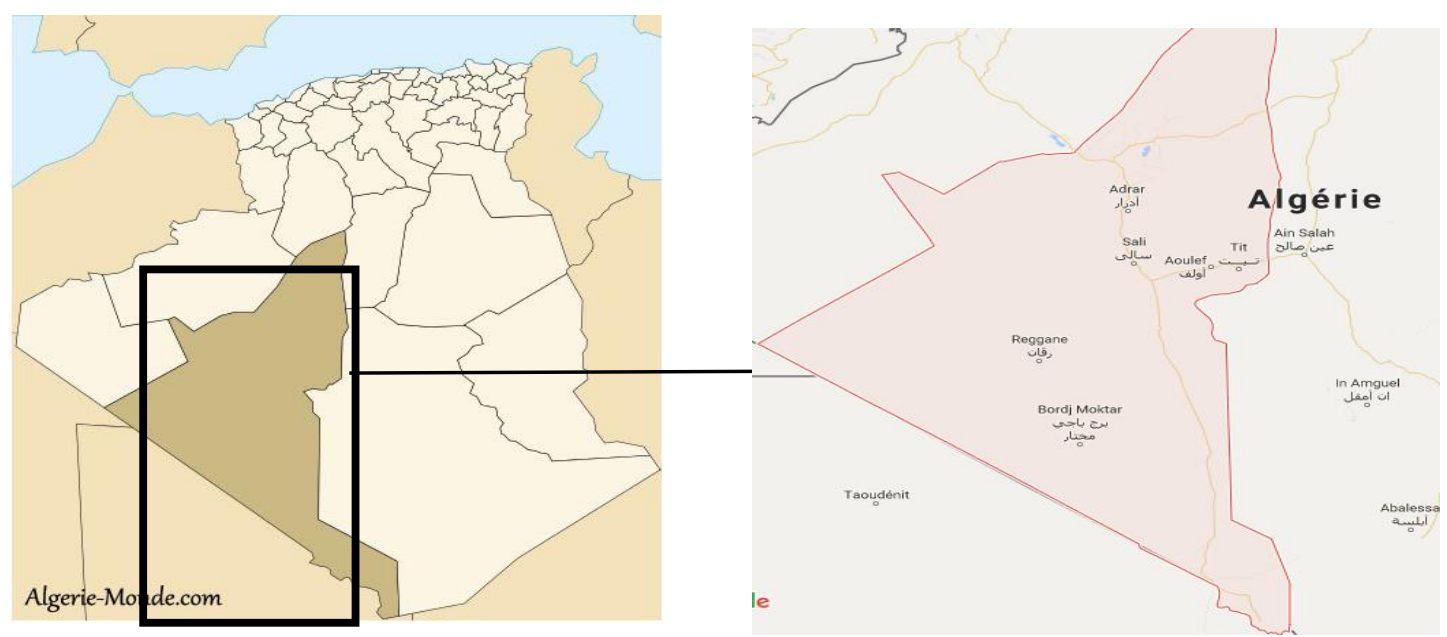

Figure 1. Geographic situation of the studied region

\section{Isolation and characterization of the pathogen}

\section{a) Field prospection}

In order to search for characteristic symptoms of the disease (Fusarium wilt of the date palm), surveys were carried out at the level of the Waina region (Adrar Province) during the month of April 2017. Variety palms Telemsou and Tgaza, presenting the typical symptoms of Bayoud, were collected for analysis in the laboratory (photo 1 and 2).

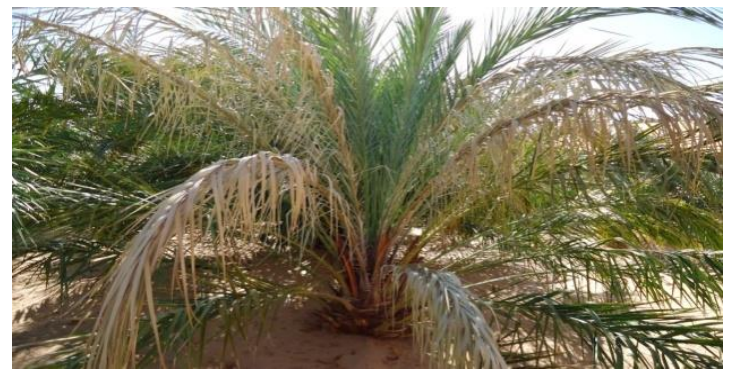

Photo.1: Bayoudée palm of the Tegaza variety (original).

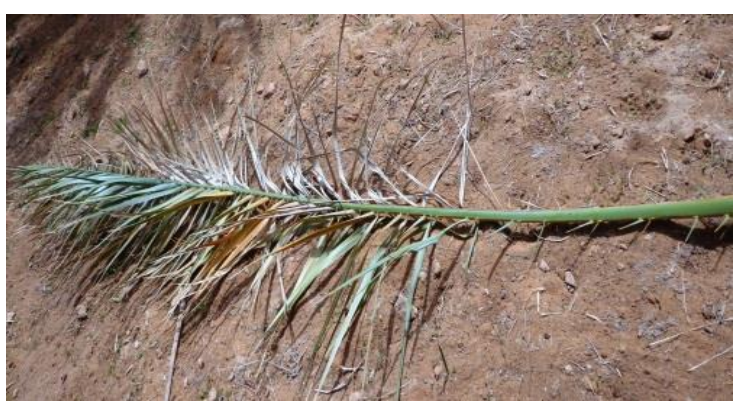

Photo.2: unilateral progression of Bayoud symptoms from the base to the top of the palm (original). 


\section{b) Isolation of Fusarium oxysporum $f . s p$. albedinis}

Isolation of the pathogen Fusarium oxysporum f.sp. albedinis is made from date palm rachis with Bayoud symptoms. They are cut into a small fragment of $2 \mathrm{~cm}$ longitudinally, and they are placed in $2 \%$ bleach for disinfected, then rinsed several times with distilled water to remove traces of bleach. The fragments are deposited in petri dishes containing solid Potato Dextrose Agar (PDA) medium. This medium is used to maintain the strains in culture. The dishes are incubated at $28{ }^{\circ} \mathrm{C}$ in the dark for 7 days (Bounaga, 1975).

c) Cloning of isolates

Purification of the strains is carried out by monosporous isolation which makes it possible to obtain a genetically homogeneous material for the study of the morphological and pathogenic variations in the clonal progeny thus obtained. Fragments of mycelial cultures, generally containing numerous conidia, are collected sterilely at the margin of a culture aged 7 days and placed in tubes containing $9 \mathrm{ml}$ of distilled water. After vigorous stirring, a drop of spore suspension is spread on the agar medium $2 \%$ contained in a petri dish. These dishes are then incubated at $28^{\circ} \mathrm{C}$. in the dark, 24 hours later, isolated microscopic lichen (the thallus derived therefrom is genetically homogeneous) is removed by sterile magnification and then transplanted into dishes of kneaded containing PDA medium (Henni et al, 1994).

\section{Morphological characterization of Fusarium oxysporum f.sp albidinis (Foa) \\ a) Macroscopic identification of Foa isolates}

This study was carried out by transplanting a $6 \mathrm{~mm}$ diameter mycelial disk (from each isolate) into Petri dishes containing a PDA medium. The morphological aspect of the colony, and its pigmentation, is carried out by direct examination with the naked eye, the diameter of the colony is measured daily during 07 days of incubation at $28^{\circ} \mathrm{C}$ (Bani, 2011).

\section{b) Microscopic identification of Foa isolates}

Foa is morphologically characterized by:

-the presence of microconidia, macroconidia and chlamydospores; the presence of short monophialides on which macroconidia can be formed in false head;

-the presence of fruiting bodies such as pionnotes and sporodochies (Bani, 2011).

\section{Conservation of isolates}

The method of conservation on slant agar is to transplant the purified fungus into tubes on the inclined PDA medium, the cultures are maintained for 3 days at a temperature of $22{ }^{\circ} \mathrm{C}$ and then stored at $5{ }^{\circ} \mathrm{C}$ to promote their viability and limit the possibilities of variations (Belabid, 2003).

\section{Results and Discussions}

Results

a) Isolation of the fungus

After surveys carried out at the Waina Adrar region, 05 Foa isolates were obtained. After 03 days of incubation, the appearance of the mycelial sectors at the ends of the fragments was noted as indicated on figure $\mathrm{n}^{\circ} 2$. Mycelial growth at the ends of the infected fragments.

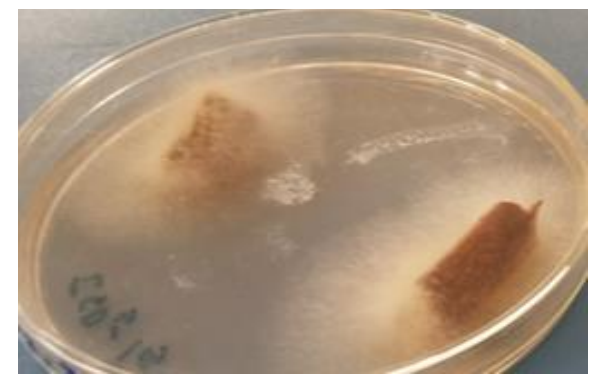

Figure. 2. Isolation of the fungus from the rachis. 


\section{b) Monospore culture}

Monospore culture aims to obtain pure cultures and facilitates macroscopic and microscopic identification (figure 3).
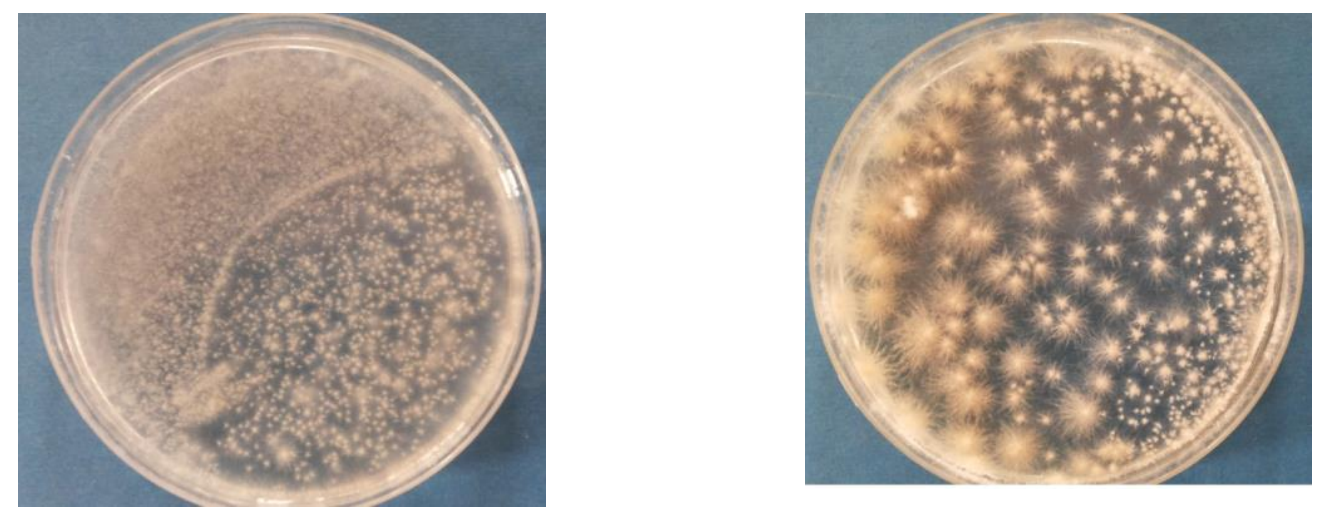

Figure 3: Monospore culture of isolates obtained

\section{b).1. Morphological characterization of Fusarium oxysporum f.sp albidinis (Foa)}

After purification of isolates by monospore culture, 02 morphotype (Figure 4 and 5) were observed. The appearance of the aerial mycelium makes it possible to identify them as follows: The cottony morphotype: has a very abundant aerial mycelium, thick and dense with a pinkish white color. In this type, microconidia are produced late (Figure 4). The mucous mucosal type: is characterized by the absence of aerial mycelium, which gives the culture a mucous appearance as if it were invaded by bacteria. Microconidia are very abundant, macroconidia are rare and chlamydospores are late but abundant (Figure 5).

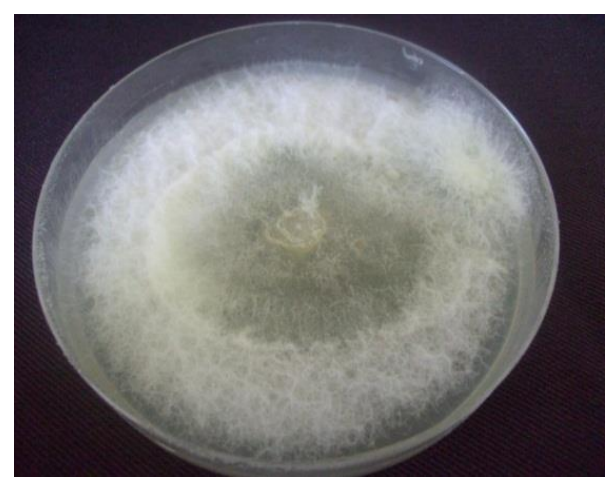

Figure 4 : Cottony morphotype

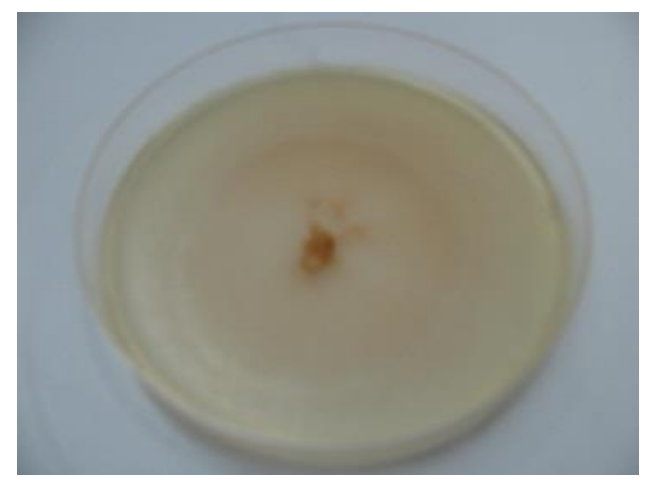

Figure 5 : Morphotype flush mucous

\section{Microscopic characterization}

Microscopic observation showed the presence of hyaline and septate mycelium, with short monophialids on which microconidia $(\mathrm{mc})$ are found, as well as the presence of macroconidia (MC) and chlamydospores $(\mathrm{CH})$. The microconidia are spherical or elongated, slightly curved, generally unicellular, hyaline, of variable size in the same culture $(3-15 \times 3-5 \mu \mathrm{m})$. Fusoid to falcipular macroconidia, pointed at both ends, generally having 3 to 5 septa, measure 20 to $35 \times 3$ to $5 \mu \mathrm{m}$. The chlamydospores are intercalary or terminal, spherical, isolated or in short chains containing 2 to 4 chlamydospores which are formed either on the mycelium or from macroconidia. These microscopic features are illustrated in Figure 6 and 7 where the different types of spores are present. 


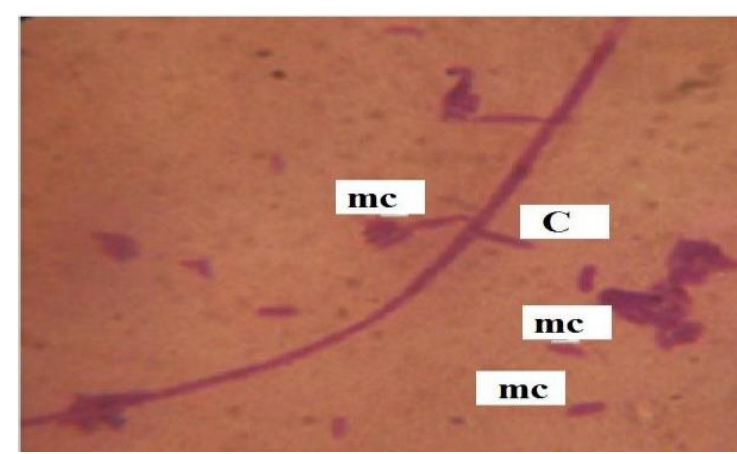

Figure 6 : Mycelium, microconidia and conidiophores of Foa

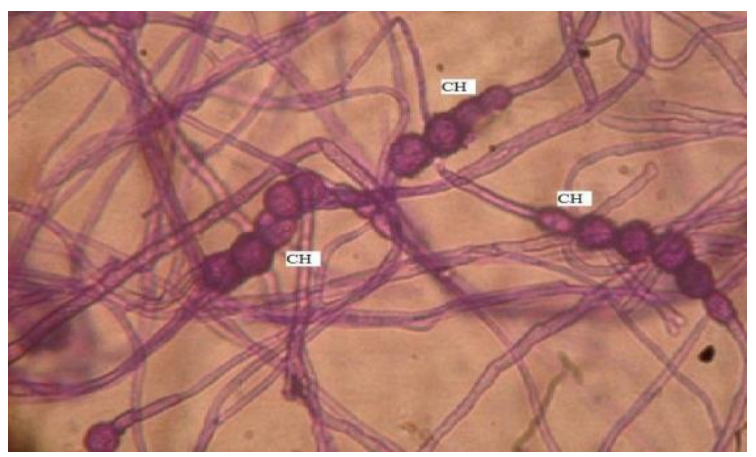

Figure 7 : Formation of chlamydospores in Foa after 15 days.

\section{Discussion}

The results obtained in this study show a variability of the morphology (macroscopic and microscopic appearance) of Fusarium oxysporum f.sp albidinis. Two morphotypes were found (cottony and mucous). These results are similar to those obtained in other forms of F.oxysporum f.sp. vasinfectum (Assigbetse, 1989), F. oxysporum f.sp. lycopersici (Henni et al., 1994) and F.oxysporum f.sp. lentis (Abbas et al, 1995). The variability of mycelial morphology has been observed in all forms of F. oxysporum (Beckman, 1981). This state of morphological variability, which undoubtedly hides an important genetic variability, means that the phytosanitary treatment that remains has not been easy to highlight and that the latter must have a broad spectrum of action.

\section{Conclusion}

The date palm (Phoenix dactylifera L.), despite its resistance to all abiotic factors, is threatened by vascular Fusarium wilt (Bayoud), a fungal disease caused by the telluric fungus Fusarium oxysporum $\mathrm{f}$. sp. albedinis. This disease has existed for more than a century in North Africa. Our work is part of the isolation and study of the morphology of the species Fusarium oxysporum f.sp. albedinis, the causative agent of Bayoud disease (Fusarium wilt) of the date palm. Laboratory isolates from samples with suspected Bayoud symptoms at the palms yielded 05 different isolates of Fusarium oxysporum f.sp. albedinis. Morphological study of isolates of Fusarium oxysporum f.sp. albedinis allowed to distinguish 02 morphotype (cottony and ras mucous). The microscopic study of the isolates obtained has shown us that the mycelium is partitioned with the appearance of the three kinds of spores; microconidia, macroconidia and chlamydospores. The results obtained during this work are highly interesting and should be complemented by a molecular study. Biological control against this pathogen that threatens the Algerian phoenicultural heritage is another path that deserves attention.

\section{References}

Abbas HK, Tanaka T, Duke SO, Boyette CD 1995. Susceptibility of Various Crop and Weed Species to AAL-Toxin, a Natural Herbicide. Weed Technology. 9(1). 125-130

Assigbetse K 1989. Etude de la variabilité spontanée chez le Fusarium oxysporum f. sp.vasinfectum SN et H. : agent de la fusariose du cotonnier. Montpellier : ORSTOM, 29 p. multigr. Mém. DEA : Phytopathol., Paris 11 : Paris. 1989.

Bani M 2011. Prospection, isolement et caractérisation phénotypique d'isolats de Fusarium oxysporum Schlechtendahl f.sp. albedinis (Killian \& maire) Essai d'antagonisme bactérien. Mémoire en vue de l'obtention du Diplôme de magister en Biotechnologies Végétale, Ecole national Supérieure d'Agronomie El Harrach Alger P 85.

Beckman CH 1981. Fungal wilt diseases of plant. Edited by Marshall E.M. and Alois A.B. p. 639.

Belabid L 2003. La fusariose vasculaire de la Lentille dans le nord -ouest algérien : Morphologie et diversité génétique chez Fusarium oxysporum f.sp. lentis. en relation avec la répartition géographique et le pouvoir pathogène. Thèse de doctorat. Université d'Oran, EsSenia.52p.

Bounaga N 1975. Germination de microconidies et macroconidies de Fusarium oxysporum f.sp.albedinis. Bulletin de Ia Société d'Histoire Naturelle d'Afrique du Nord. 60: 39-44 
Brac de la Perrière RA, Benkhalifa A 1991. Progression de la fusariose du palmier dattier en Algérie. Sécheresse 2: 119-128.

Djerbi M 1982. FAO Regional Projet for palm and Dates Research,

Henni J. Boisson C. Giger JP 1994.Variabilté du pouvoir pathogène chez les Fusarium oxysporum f.sp. Lycopersici. Phytopathol Mediterr. 33: 51-58.

Kebir M 2011. Etude et analyse des données météorologiques, en particulier le Vent dans la région d'Adrar. Mémoir de Master, Université de Tlemcen.

Pereau-Leroy P 1958. Le palmier dattier au Maroc. Ministère de l'Agriculture (142 pp.). Instit Franc Rech Outre-mer, Paris.

Sedra MyH, 1995. Triage d'une collection de génotypes de palmier dattier pour la résistance au Bayoud causé par Fusarium oxysporum f.sp. albedinis. INRA-Rabat Maroc. Al Awamia 90: 9-18

Sedra MyH, 1999. Prospections et importance du Bayoud en Mauritanie et actions urgentes à prendre pour lutter contre la maladie. Rapport de mission de consultation FAO effectuée du 19/10/99 au 18/11/1999 en République Islamique de Mauritanie et proposition de projet de lutte contre le Bayoud dans ce pays. Mission financée par le projet Développement des Oasis, phase II, UFT/MAU/020//MAU

Sedra MyH 2003a. Le Bayoud du palmier dattier en Afrique du Nord, FAO, RNE/SNEA-Tunis. Editions FAO sur la protection des plantes. Imprimerie Signes,Tunis, Tunisie, $125 \mathrm{p}$

Sedra MyH 2005a. Caractérisation des clones sélectionnés du palmier dattier et prometteurs pour combattre la maladie du Bayoud. The international symposium: sustainable agricultural development of oasian systems, Erfoud Morocco 